\title{
FOREIGN DIRECT INVESTMENT AND ECONOMIC GROWTH IN ALBANIA
}

\author{
Ylvije Kraja Boriçi; Elezi Osmani \\ University of Shkodër "Luigj Gurakuqi", Albania - Faculty of Economics
}

\section{ABSTRACT}

Since the 1980s, foreign direct investment inflow (FDI) has grown significantly in most developing countries while pertaining Alania, foreign direct investment has started after the 1990s. A lot of developing countries have made policies aimed at reducing FDI barriers. Foreign capital globalization, particularly FDI inflow is increased significantly in developing countries, due to the fact that FDI is the most stable and prevalent component of foreign capital inflows (Adams, 2009) Foreign direct investments are a very important factor for the development of a country and Albania has still much to be done to encourage such investments, especially in the legislative framework. The authors are trying to give the answer to the question that how does foreign direct investment in the Albania affect the nation's economy? The authors identify that foreign direct investment improves technology and has positive impact on economic growth. Because the overall theory is that FDI inflow enhances and sustains economic growth in the host country.

Keywords: FDI foreign direct investment, inflow, European integration, government policy.

\section{INTRODUCTION}

One of the main debates in the economic literature was impact of Foreign Direct Investment in economic growth in the developing countries. Foreign direct investment have been an engine of economic growth in an increasingly globalized world economy, and has been one of the most important subjects in the study of international business. Foreign Direct Investment FDI can be explained as the investment which is being invested by an investor in foreign countries having interest to gain more market share in the international contest and having the economies of scale (Shaari, Hong \& Shukeri, 2012). Foreign direct investment is flowing of capital by an investor who buys a property/asset in another country to manage it (Denisia, 2010). Foreign Direct Investment play an important role in Albanian industry and ensuring the competition of the Albanian products in the world market. FDI might help to fill out the gap between the Albanian industrial capacity and the continuous facilities.

FDI have three components:

1. New equity from the parent company to its branch in the host country;

2. Reinvested profits of the foreign company branch in the host country;

3. Short-term loans and long term loans from the parent company to its subsidiary in the host country.

Foreign Direct investment play the significant role as a source of financing a lot of developing countries (Moosa \& Cardak, 2002). FDI can also generate domestic investment in matching funds, facilitate transfer managerial skills, increase market competition, create job opportunities, all of which contribute to economic growth (Quazi, Vemuri, \& Soliman, 2014). Foreign direct investment fill development gaps, as investment gap by providing capital for investment, foreign exchange gap by providing foreign currency through investments and export earnings, and also tax revenue gap by generating tax revenues (Ibidem). It is important having policies developed by central and local government improving the infrastructure, which creates opportunities for businesses (Kraja Boriçi \& Osmani, 2014). 
De Mello (1997) adds that FDI enhances growth through capital accumulation by:

1. Introducing new inputs.

2. Using a wider variety of intermediate goods in FDI-related production and technologies.

\section{PRIORITY SECTORS FOR ATTRACTING FOREIGN DIRECT INVESTMENT}

Based on the geographical positon of Albania, the highest percentage of FDI is originated by European Countries. The foreign subjects that have invested in Albania are mainly neighburhood countries. The foreign firms or subjects that have invested in Albania have positively influence in employement and also in the growth of our economy. But, economic and financial crise that has include the countries of our region has influenced the decrease of the foreign direct investment in Albania.

Potential for development of the domestic economy created by the development of the agro-food industry, timber manufacturing industry, mineral extraction industry, construction materials industry and tourism. Law on Tourism, particularly, creates more tax incentives and encourages investors.

The Albanian mining sector has considerable mineral resources extraction including chromium, copper, nickel, coal, which are all extracts. Quantity and quality of chromium is high.

At the end of 1990 most of the foreign investments in the Central and Eastern Europe countries include the extractive industry, the cement and construction materials. Albania has unlimited reserves of limestone and copper. Foreign Direct Investment in drilling equipment and research in the field of oil could help revitalize damaged equipment Albanian insurance coverage rates, increasing economic efficiency, and the discovery of additional reserves of oil and gas. An objective investment strategy could define and promote foreign investment.

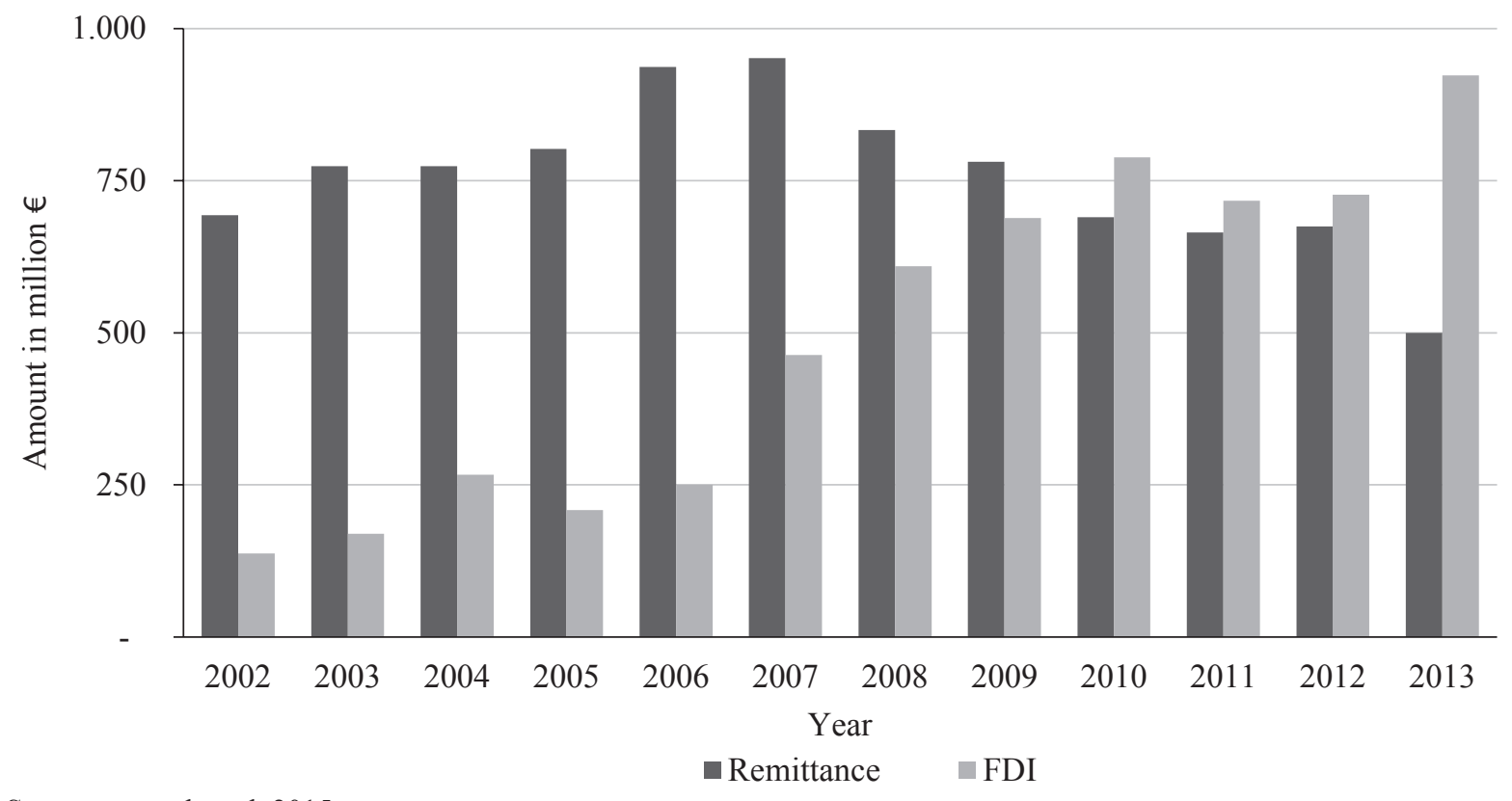

Source: open.data.al, 2015

Graph 1. Remittance and Foreign Direct Investment

Tourism: Albania has a lot of interesting mountains, grasslands, forests, rivers and lakes, and an wonderful coastal space, cultural heritage, ancient castles, often combined brilliantly, which makes the nature of our country special and quite different and attractive for tourist activities. The current prospects for FDI to the tourism sector in Albania are limited by the development of infrastructure and lack of tourist facilities. These factors influence the 
creation of a good imagine they also help to create more perspective than current tourism. Initially foreign investments in tourism could be developed into tourist villages.

The main purpose of the study is to find out the impact of foreign direct investment on economic growth and to analyse some issues which are fundamental in sustaining growth and development in Albania following the impacts of foreign direct investment.

In this paper are used a combination of the secondary and primary sources.

The main objectives:

1. The main objective of the study is to find out the impact of foreign direct investment in economy.

2. To find out the relationship between foreign direct investment and economic growth.

3. Investigating how the lack of technology can affect the inflow of foreign direct investment in Albania.

4. Investigating how the government policies can affect the inflow of foreign direct investment in Albania.

Research question: Is there internal environment having greater impact in creation of the competitive advantage to SMEs than external environment?

Hypothesis: Economic growth has positive relationship with foreign direct investment (FDI) inflow.

\section{LITERATURE REVIEW}

Scholars of international business have accumulated an expansive knowledge of the subject. However, there are some deficiencies in the literature. First, most research on foreign investment have focused on foreign direct investment (FDI), whereas the topic of foreign indirect investment, or foreign portfolio investment (FPI), has received less attention (Li \& Filer, 2007). This leads to a second deficiency in the literature. The relationship between foreign direct investment and indi- rect investment has not been sufficiently examined. When the proportion of FDI as a percentage of the total foreign investment into a country versus the level of the rule of law of the receiving country is plotted, it is clear that countries with a lower level of the rule of law have a higher proportion of FDI (Ibidem).

There is strong empirical evidence that FDI flows are less volatile than other capital flows (IMF, 2007). Various international organizations and foreign advisors suggested that developing countries should focus primarily on foreign direct investment FDI as a source of external finance (Velnampy, Achchuthan, \& Kajananthan, 2014). Foreign direct investment are investment done in a country by an investor who buys a property, asset in another country to manage it.

Foreign direct investment has three components:

1. New equity from the parent company to its branch in the host country.

2. Reinvested profits of the foreign company branch to the host country.

3. Short term and long term loans from the parent company to its subsidiary in the Foreign direct investment is an investment done in a country by an investor who buys a property, asset in another country to manage it. Flavianus (2012) shows that "developing countries are increasingly aware of the role of foreign direct investment as an engine of growth in their economies". The management, ownership, and control is what distinguishes FDI from portfolio investment (Ball, McCulloch, Frantz, Geringer \& Minor, 2002). Foreign investment includes two categories: direct investment and portfolio investment. In direct investment, investors invest capital into a firm for a return on the investment and has the right to participate in the management of the firm. In contrast, in portfolio investment, investors purchase securities (such as stocks and bonds) for a return on their investment (Wu, Li \& Selover, 2012). Investments of capital inflow in 
the country in the form investment in new businesses, or as cross-border mergers and acquisitions

\section{SWOT ANALYSIS}

Macroeconomic stability and economic growth are essential for promoting economic development. For corporate investors, the most important indicators of macroeconomic stability are those that directly affect their balance sheets, such as GDP growth and GDP/ capita, inflation, population growth and the rate of university education. Also, the interest rate is very important for SMEs and some foreign investors. Opening a country to foreign trade, foreign investors and foreign workers, has its impact on success in promoting economic development.

Many theoretical and empirical attempts have identified the factors that can enhance economic growth and performance in order to provide suggestions for policymakers to fill the gap between developed and developing countries, and to create sustainable development (De Jager, 2004).

Managers should be sensitive toward external environment which is so dynamic, and which extremely influence the decision making (Kraja Borici, \& Osmani, 2015).

\section{Strengths}

1. Albania is reach in natural resources, investment in resources is an great chance for foreign investitors and even for albanian investitors.

2. As it was mention above there are a lot of raw materials.

3. In Albania because there is a high percentage of unemployement it is possible to find skilled workforce with low cost.

4. Our country has a lot of attractive places, intresting plots.

5. Favorable geographical position in most regions and markets in Europe.

6. It is easier for foreing firm to invest in Al- banian economy because the competition is not as strong, in meaning that the competition for resident firms is relatively low compared with foreign ones.

\section{Weaknesses}

1. Sometimes safety and peace is not prezent.

2. In our economy dominates small domestic markets.

3. There is low income per capita.

4. In our economy there is poor infrastructure.

5. Industrial technology obsolete.

6. Weak financial sector.

7. An inefficient legal framework for investment.

8. Hassle costs, that is connected with corruption and inefficiency.

9. Informal economy creates problem for foreign investitors that want to work conform the laws. Like problems pertaining the properties etc.

\section{Opportunities}

1. Already there are great opportunities for European integration, because Albania is the member of several international Associations. Regional economic integration.

2. Wide diaspora.

3. Time after time there are done great reforms of the education system.

4. Rebuilding infrastructure.

5. Central and local governement can create trade policy and facilities for foreign investitors to invest in our economy etc.

6. Foreign investitors can operate in all sectors of our economy. Our economy is open to all of them that want and have possibilities to invest to us, foreign or resident investitors.

\section{Threats}

1. Competition of neighbouring countries.

2. The lack of economic stability. 
3. Law and safety is unstable.

4. The increase in wages and loss of competitive advantage of low labor costs

5. Competition of neighboring countries.

There are some critical factors that have their impatc in Foreign Direct Investment (FDI).

1. Political factors that include: stability and political risk, signed agreement or international convents A political stability will increase investment even for the long run period.

2. Economic factors that include: the population of the country, quality and price of the workforce, infrastructure, energy, inflation, income per capita etc, all these factors have their impac on FDI. In general the investments go towards the countries that have high level of living or a growth of income per person. .

3. Social factors that include the attitude toward the foreign capital.

4. Techonologic factors that include, the necessety of changing technology through the investment.

This study has limitation. Future research should rely on the other factors affecting FDI into the country such as political factors, knowledge.

\section{CONCLUSIONS AND RECOMMANDATIONS}

Albania as developing country should focus on foreign direct investment (FDI) as a source of external finance. Investors may have full control in the short run by simply selling their investment. However, they do not have control in the long-run.

Inflows of FDI in Albania over the years have changed. FDI flows have increased significantly since 1990s. The main reasons for the level of foreign investment are: political and economic instability, the perceived risk; lack of accountability and institutional capacity, poor implementation of the law, inefficiency and low cost infrastructure, delays in devel- oping a comprehensive strategy of economic and social development etc. Central and local government play no proper role in relation to the function to be carried out, also because of poor connections with investors. Environmental Governance explains why there are still many countries that attract little foreign investment thereby limiting their productivity and prosperity even though foreign investments are an engine of economic growth worldwide. There is low support from other state institutions. Low interest of foreign investors is due to the perception of a high risk associated with political changes in Albania and the lack of stability in the Balkans.

Albania has some potential sectors and good opportunities for attracting FDI, especially in tourism, agriculture, telecommunications, infrastructure, services, transport etc. Should be improved the climate of the environment in which FDI operate, in order to attract more FDI. To focus the energies of the country in service to existing investors and attract potential investors.

Become better publicity for Albania in the context of the requirements of investors that they stay in lasting and consistently, and increasing their investments. To work more on marketing the territory, aiming at improving the country's image.

Develop and rich incentive policies to attract foreign investment in priority sectors, already determined by the Albanian government.

Increase the states regulatory role on the market, the development of competition and the elimination of the informal economy, guarantee property rights and resolve conflicts inherited. Maintaining economic growth and deepen economic reforms.

\section{LITERATURE}

Adams, S. (2009). Foreign Direct investment, domestic investment, and economic growth in Sub-Saharan Africa. Journal of Policy Modeling, 31, 939-949. 
Asiedu, E. (2006). Foreign Direct Investment in Africa: The Role of Natural Resources, Market Size, Government Policy, Institutions and Political Instability. World Economy, 29, 63-77.

Ball, D., McCulloch, W., Frantz, P., Geringer, M. \& Minor, M. (2002). International business: The challenge of global competition. Boston: McGraw-Hill.

De Jager, J. (2004). Exogenous and Endogenous Growth. University of Pretoria ETD.

De Mello, J. (1997). Foreign direct investment in developing countries and growth: A selective survey. Journal of Development Studies, 34, 1-34.

Denisia, V. (2010). Foreign Direct Investment Theories: An Overview of the Main FDI Theories. European Journal of Interdisciplinary Studies, 2, 104-110.

Flavianus, M. M. (2014). Determinants of Foreign Direct Investment in East Africa Countries of Tanzania and Kenya: The case study of Tanzania and Kenya. Retrived November, 11, 2015, from http://www.clknet.or.tz/wp-content/ uploads/2013/03/DETERMINANTS-OFFOREIGN-DIRECT-INVESTMENTSFDIs-IN-EAST-AFRICA-COUNTRIESOF-TANZANIA-AND-.pdf

IMF. (2007). World Economic Outlook. Autor.

Kraja Boriçi, Y. \& Osmani, E. (2014). The role of the Government Policy for support the SME-s. Academic Journal of Interdisciplinary Studies, 3, 391-396.

Kraja Boriçi, Y. \& Osmani, E. (2015). Importance of external and internal environment in creation of competitive advantage to SMEs. (Case of SMEs, in the Northern Region of Albania). European
Scientific Journal, 11, 120-130.

Li, S. \& Filer, L. (2007). The effects of the governance environment on the choice of investment mode and the strategic implications. Journal of World Business, 42, 80-98.

Moosa, I.A. \& Cardak, B.A(2002). The determ inants of Foreign Direct Investment in MENA countries: An extreme bounds analysis. Journal of Multinational Financial Management, 16, 199-211.

Open.data.al. (2015). Remitanca dhe IHD. Retrived November, 14, 2015, from http://open.data.al/uploadserise/skedaret/ remitancat_dhe ihd_Shqip.xls

Quazi, R., Vemuri, V. \& Soliman, M., (2014). Impact of Corruption on Foreign Direct Investment in Africa. International Business Research, 7, 1-10.

Senkuku, A. M., Gharleghi, B. (2015). Factors Influencing Foreign Direct Investment Inflow in Tanzania. International Journal of Business and Management, 10, 48-56.

Shaari, M. S. B., Hong, T. H. \& Shukeri, S. N. (2012). Foreign Direct Investment and Economic Growth: Evidence from Malaysia. International Business Research, 5, 100-106.

Velnampy, T., Achchuthan, S. \& Kajananthan, R. (2014). Foreign Direct Investment and Economic Growth: Evidence from Sri Lanka. International Journal of Business and Management, 9, 140-148.

Wu, L., Li, S. \& Selover, D. D. (2012). Foreign Direct Investment vs -Foreign Portfolio Investment The Effect of the Governance Environment. Management International Review, 52, 643-670. 